\title{
WHICH IS GREENER? THE GAS CONDENSER BOILER OR GROUND SOURCE HEAT PUMP. WHICH IS THE CONTRIBUTION OF RENEWABLE ENERGY TO THE ENERGY CONSUMPTION FOR HEATING TO A BUILDING?
}

\author{
I. L. Cîrstolovean \\ University Transilvania Brasov, Faculty of Buildings Engineering, Romania, e-mail: luceoe@ yahoo.com
}

Received: 10.09.2015 / Accepted: 10.10.2015 / Revised: 25.10.2015 / Available online: 15.12.2015

DOI: 10.1515/jaes-2015-0015

KEY WORDS: RER, technologies, $\mathrm{CO}_{2}$ Emissions

\begin{abstract}
:
The goals of this paper are: to estimate the carbon emission reduction on energy efficiency measurements in a laboratory building in Transilvania University from Braşov, Romania, in accordance with the European Directive 2009/28/EC and to estimate the contribution of renewable energy to energy efficiency of the building using the performance indicator named Renewable Energy Ratio - RER. We will detail the methods of calculation for $\mathrm{CO}_{2}$ emissions and we will present the results for gas condensing boiler, and ground source heat pump for the laboratory building. The results show that conventional energy efficiency technologies and renewable energy technologies can be used to decrease $\mathrm{CO}_{2}$ emissions in buildings by $20-30 \%$ on average and up to over $40 \%$ for some building types and locations. The contribution of renewable energy is between 40 and 50 $\%$ from total energy use and only for heating is $58 \%$. This value could rise to 0.63 if we apply to electricity produced by photovoltaic panels.
\end{abstract}

\section{INTRODUCTION}

Buildings are responsible for $40 \%$ of total $\mathrm{CO}_{2}$ emissions in the world. Combustion of fossil fuels produces $\mathrm{CO}_{2}$ gas which is recognized as the major greenhouse gas causing global warming. To reduce the $\mathrm{CO}_{2}$ emissions associated to the buildings sector we must increase the energy efficiency of the buildings and utilization of low carbon energy technology to supply the heating demands of the buildings. Heat pump is a low carbon technology proposed to be used in buildings. This technology has been considered in the European Directive 2009/28/EC which is the main directive for proportion of renewable energy in the EU's buildings sector (SADR F 2014, European Directive 2009/28//EC).

The Net Zero Energy Building concept is already well known. Recent studies have attempted to designate energy efficiency, environmental effects in buildings and building materials (Yüksek, 2015). Kumar et al. (2012) have discussed the use of 
embodied energy and total energy for a given sample room.

The paper focuses upon the comparison between two types of structures using fire clay bricks and ash blocks structure. Though ash blocks are 3 times costlier than fire clay bricks, the use of ash blocks has considerably reduced the size of the air conditioning system, the total usage of energy and finally the total cost of building due to its light weight and insulating feature (Kumar, 2012; Yüksek, 2015). Jayasinghe has investigated and developed the embodied energy of different building materials (conventional building materials and alternative building materials). This study has also included the performance of different materials on operational energy.

It is shown that the alternative building materials (cement stabilized soil blocks and stabilized rammed earth for walls, micro-concrete roofing tiles for roof and pre-cast reinforced concrete slab systems for floor) and systems may have either reduced or similar impact on life cycle cost, compared to the conventional building materials. According to the result of this paper, the embodied energy of alternative systems is either lower than or comparable to most of other conventional systems (Jayasinghe, 2001; Yüksek, 2015). Bribian et al. (2011) present the results of a Life Cycle Assessment study comparing the most commonly used building materials (Steel, aluminum, copper, PVC and glass) with some eco-materials (Brick and tiles, insulation materials, cement and concrete, wood products) using primary energy demand, global warming potential and water demand impact categories.

The aim of the study is to deepen the knowledge of energy and environmental specifications of building materials, analyzing their possibilities for improvement and providing guidelines for the selection of materials in the eco-design of new buildings and rehabilitation of existing buildings (Bribian, 2011; Yüksek, 2015). Lee et al. explore the impact of different building materials (concrete vs steel) on the embodied energy of the building structure and compare them with the Green Building Rating score attained under the material category for the same structure. As a result of the study, the embodied energy of the whole concrete structure is more significant than that of the steel or the hybrid structure. Besides this, the impact of building materials not only is limited to the embodied energy and the demolition energy but also to the operational energy of the building (Lee, 2011; Yüksek, 2015). Reddy's paper focuses on certain issues pertaining to energy, carbon emissions and sustainability of building construction with particular reference to the Indian construction industry. Some examples of alternative low-energy materials (Blended cements, stabilized mud blocks, compacted fly ash blocks, rammed earth walls, composite masonry jack-arch roof system) were discussed and the embodied energy analysis of a building using such materials was compared with that of a conventional building (Load-bearing brickwork, reinforced concrete solid slab floor and roof, concrete tile flooring).

The analysis shows that embodied energy of buildings using the low energy materials and techniques results in 50\% savings in total embodied energy. There is a large potential and scope for using the industrial and mine solid wastes for the manufacture of building materials for promoting sustainable construction practices (Reddy, 2009).

"European and national laws ask for an increased ratio of renewable energy sources and carriers of the total energy consumptions of buildings. While the Renewable Energy Directive gives only a framework for national implementations in the EU and the Erneuerbare-Energien-Warmegesetz in Germany focuses on the partial coverage or the thermal energy demands of buildings or similar compensatory measures" (Lazzarin, 2012). REHVA introduces a performance indicator to calculate the actual fraction of used renewable energy sources. It is named "Renewable Energy Ratio (RER)" and suggested in a similar manner in the proposal of the recast of DIN EN 15603-2013 where it is named "Share of renewable energy" (Musall \& VOSS, 2014). In EN 15603 (prEN15603:2013) CEN defines the renewable energy ratio as the ratio of the renewable primary energy (calculated with renewable primary conversion factor), of the total primary energy (calculated with total primary conversion factor). 
The goals of this paper are to apply the Renewable Energy Directive to the laboratory building, more precisely to determinate the performance indicator "Renewable Energy Ratio (RER)" and to justify why we chose the gas condensing boiler and the heat ground source according to the reducing $\mathrm{CO}_{2}$ emission Directive. We will present the methods and the result of the calculus.

\section{MATERIALS AND METHODS}

\subsection{The RER - concept (Musall \& Voss, 2014)}

"The total amount of the primary energy from the renewable sources results from the difference between the total primary energy and non-renewable primary energy of all observed energy flows which cross the balance boundaries. All conversion and system losses within the balance boundary are included" (Musall \& Voss, 2014). "Energy losses outside of the balance boundary are represented by primary conversion factors of the various energy carriers". According to the draft from REHVA, "the formula below applies for calculating the Renewable Energy Ratio (RER)" (Musall \& Voss, 2014; Zirngibil, 2014; Marszal, 2011):

$R E R_{p}=\frac{\sum_{i} E_{r e n, i}+\sum_{i}\left(\left(f_{\text {del }, \text { tot }, i}-f_{\text {del, }, \text { ren }, i}\right) E_{\text {del }, i}\right)}{\sum_{i} E_{\text {ren }, i}+\sum_{i}\left(E_{\text {del }, i} f_{\text {del }, \text { tot }, i}\right)-\sum_{i}\left(E_{\text {exp }, i} f_{\text {exp }, \text { tot }, i}\right)}$

where:

$R E R_{p}=$ is "the Renewable Energy Ratio based on total primary energy";

$E_{\text {ren }, i}=$ is the "renewable energy produced on the site or nearby for energy carrier i";

$E_{d e l, i}=$ is the "delivered energy for energy carrier i"; $E_{\text {exp }, i}=$ is the "exported energy for energy carrier i"; $f_{\text {del }, \text { tot }, i}=$ is the" total primary energy factor for the delivered energy carrier i";

$f_{\text {del,nren, } i}=$ is the "non-renewable primary energy factor for the delivered carrier i"; $f_{\text {exp }, t o t, i}=$ is the "total primary energy factor of the delivered compensated by exported energy carrier i".

\subsection{CO2 emissions with gas fired boiler (Sadr,} 2014)

Where a gas fired boiler is used to supply the heating demand of building, the annual emission rate can be calculate from the following equation (1):

$$
e_{h}=F_{b} k_{b}=\frac{H}{\eta_{b}} k_{g}
$$

where:

$e_{h}$ is annual emission rate;

$F_{b}$ is the fuel energy imput to the boiler: $\mathrm{H}$ is the heating demand of the building;

$\eta_{b}$ is the thermal efficiency of the boiler;

$k_{g}$ is the emissions factor of the mains natural gas.

2.3. $\mathrm{CO}_{2}$ emissions with a heat pump (Sadr, 2014).

Where a heat pump is used to supply the heating demand of the building, the annual emission rate , can be calculate from the following equation (1):

$$
e_{h}=E_{h p} k_{e}=\frac{H}{C O P} k_{e}
$$

where:

$e_{h}$ is annual emission rate;

$E_{h p}$ is the electrical energy input to the heat pump,

$k_{e}$ is the grid emissions factor,

$\mathrm{H}$ is the heating demand of the building and

COP is the heating coefficient of performance.

\section{RESULTS}

The building studied in this paper, a research laboratory, where the heat pump was implemented, has a reduced head necessary. The structure of the envelope was designed in such a way as to respond to the Directive which requires cuts on the energetic consumption of buildings. In this way, it was 
possible to use as source for the production of the thermal agent a soil-water heat pump.

The heat naturally accumulated in the crust triggers what is called geothermal energy. The soil has the property of accumulating and maintaining solar energy for a longer period of time, which leads to an almost constant level of the heat source throughout the whole year (ENERGUIDE 2004). The energy is captured by the soil, either directly under the form of radiations, or indirectly under the form of heat from rains or air.

The projection and positioning of the installation of geothermal collectors in combination with the heat pump was made by having the following data (Ashrae, 2001; VIESSMANN instruction for heat pumps):

1. The necessary heating and the performance factor, $22 \mathrm{kw}$ and $\mathrm{COP} 4$, vaporization capacity 16.5 kw.

2. The volumetric flow of the heat pump, $4400 \mathrm{l} / \mathrm{h}$.

3. The specific earth-extraction capacity, $15 \mathrm{~W} / \mathrm{m}^{2}$. The geothermal tubes are double profile $U$. The characteristics for a tube are:

- $\quad$ Length $-100 \mathrm{ml}$

- $\quad$ The tube type is Pe Xa De $32 \times 2.9$ with $0.5311 / \mathrm{m}$.

- The agent quantity for a tube is 2181.

The total heat necessary for the heating of the building is of $54 \mathrm{~kW}$, calculated with (SR EN 1907/1/1997).

The heating annual energy consumption for the laboratory is: $92,34 \mathrm{kWh} /\left(\mathrm{m}^{2}\right.$ year).

For gas condensing boiler the emission factor is $0,158 \mathrm{~kg} \mathrm{CO} / \mathrm{kWh}_{\text {heat }}$ and the $\mathrm{I}_{\mathrm{CO}_{2}}$ emission is:

$$
I_{C_{2}}=92,34 \mathrm{kWh} /\left(\mathrm{m}^{2} \text { year }\right) * 0,158 \mathrm{kgCO}_{2} / \mathrm{kWh}_{\text {heat }}
$$

$I_{\mathrm{CO}_{2}}=14,58 \mathrm{~kg} \mathrm{CO} / \mathrm{m}^{2}$ year

Reducing $\mathrm{CO}_{2}$ emissions by installing a heat pump is determined based on emission factors for specific fuel gas condensing boiler $(0.158 \mathrm{~kg} \mathrm{CO} 2 /$ $\mathrm{kWhheat}$ ) and efficiency of its operation in real conditions $(\eta=0.98)$. Reducing will be:

$\operatorname{Red~} \mathrm{CO}_{2}=\frac{I_{f}}{\eta}-\frac{I_{e}}{C O P}$

$\operatorname{Red~} \mathrm{CO}_{2}=\frac{0,158}{0,98}-\frac{0,231}{4,1}$

$\operatorname{Red~} \mathrm{CO}_{2}=0,105 \mathrm{~kg} \mathrm{CO}_{2} / \mathrm{kWh}_{\text {heat }}$

And emission factor is $0,158-0,105=0,0531 \mathrm{~kg}$ $\mathrm{CO}_{2} / \mathrm{kWh}_{\text {heat }}$

For heat ground sources the emissions factor is $0,0531 \mathrm{~kg} \mathrm{CO} / \mathrm{kWh}_{\text {heat }}$ wich is mean that $\mathrm{I}_{\mathrm{CO}_{2}}$ emission is:

$I_{C_{2}}=92,34 \mathrm{kWh} /\left(\mathrm{m}^{2} \mathrm{an}\right) *, 00531 \mathrm{~kg} \mathrm{CO} 2 / \mathrm{kWh}_{\text {heat }}$

$I_{\mathrm{CO}_{2}}=4,90 \mathrm{~kg} \mathrm{CO} / \mathrm{m}^{2}$ year

The energy taken by the heat pump from the ground $(\mathrm{COP}=4)$ is $69,55 \mathrm{kWh} /\left(\mathrm{m}^{2}\right.$ year $)$.

$92,34 \mathrm{kWh} /\left(\mathrm{m}^{2}\right.$ year $) / 4=23,08 \mathrm{kWh} /\left(\mathrm{m}^{2}\right.$ year $)$

$92,34 \mathrm{kWh} /\left(\mathrm{m}^{2}\right.$ year $)-23,08 \mathrm{kWh} /\left(\mathrm{m}^{2}\right.$ year $)=$ $69,55 \mathrm{kWh} /\left(\mathrm{m}^{2}\right.$ year$)$

In Romania $20 \%$ from electricity is generated using renewable energy and $80 \%$ is generated using fuels.

- $\quad$ the primary energy factor non-renewable is zero and the total primary energy factor non-renewable in Romania is $1 / 0,36=2,8$ ):

$f_{\text {del,nren,el }}=0 * 0.2+2.8 * 0.8=2.24$ 
- $\quad$ the total factor of renewable energy is 1 and the total primary energy non-renewable in Romania is $1 / 0,36=2,8$ :

$f_{\text {del, tot }, e l}=1 * 0.2+2.8 * 0.8=2.44$

The performance indicator „Renewable Energy Ratio (RER)" is:

0.589

$$
R E R=\frac{69.55+(2.44-2024) 23.08}{69.55+(23.08) 2.44}=
$$

If we apply to electricity produce by fotovoltaic panels in site, $15\left(\mathrm{kWh} / \mathrm{m}^{2}\right.$ year $)$, the indicator RER is:

$R E R=\frac{15+69.55+(2.44-2024) 23.08}{15+69.55+(23.08) 2.44}=0.63$

\section{CONCLUSIONS}

"The attention given to the Zero Energy Building concept increased during the last years. Many countries have already established ZEBs as their future building energy target".

Among different strategies for decreasing the energy consumption in the building sector, ZEBs have the promising potential to significantly reduce the energy use and the $\mathrm{CO}_{2}$ emission, and as well to increase the share of renewable energy. In this paper we present a simple case, the energy for heating the building is provided by a gas condenser boiler coupled with a ground heat pump. The value of the $\mathrm{CO}_{2}$ emission will drop if we use a heat pump, replacing the gas condensing boiler, for heating from 14.58 to $4.90 \mathrm{CO}_{2} / \mathrm{m}^{2}$ per year, $20-30 \%$ on average. The RER indicator is 0,58 and could rise more if we apply to electricity produced by photovoltaic panels to 0.63 .

So, here is an argument for replacing classic gas boilers until 2020 with gas condensing boilers coupled with heat pumps and photovoltaic panels.

\section{REFERENCES}

ASHRAE Fundamentals HandBook, 2001, chapter 31.

Bribian I., Capilla A., Uson A., 2011, Life cycle assessment of building materials: Comparative analysis of energy and environmental impacts and evaluation of the eco-e_ciency improvement potential, Building and Environment, 46(5), 1133-1140, DOI 10.1016/j. buildenv. 2010.12.002 .

http://eur-lex. Europa.eu/2009/28//EC.

ENERGUIDE, 2004, Heating with Heat Pump, Natural resources Canada's Office of Energy Efficiency ISBN 0662-37827-x.

Ízzet Yüksek, 2015, The Evaluation of Building Materials in Terms of Energy Efficiency, Periodica Polytechnica European Directive Civil Engineering 59(1), pp. 45-58, DOI:10.3311/PPci.7050.

Jayasinghe C., 2001, Embodied energy of alternative building materials and their impact on life cycle cost parameters, in: The International Structural Engineering and Construction Society (ed.), Conference Proceedings, pp. 1-20.

Johnston, W., Narsilio, G.A., Colls, S., 2011, Energing Geothermal Energy technologies. KSCE journal of Civil Engineeing 15(4):643-653, DOI 10.1007/s 12205-0110005-7.

Kumar A., Buddhi D., Chauhan D.S., 2012, Indexing of Building Materials with Embodied, Operational Energy and Environmental Sustainability with Referenceto Green Buildings, Journal of Pure and Applied Science \& Technology, 2(1), pp. 11-22.

Lee B., Trcka M., Hensen J.L.M., 2011, Embodied energy of building materials and green building rating systems a case study for industrial halls, Sustainable Cities and Society, 1(2), pp. 67-71, DOI 10.1016/j.scs.2011.02.002.

Lazzarin, R, Busato, F., Noro, M., 2012, Heat pumps in refurbishment of existing buildings.

Marszal A.J., Heiselberg P., Bourrelle J.S., MUSAL E., Voss I., Sartori I., Napolitano A., 2011, Zero Energy Building-A review of definition and calculation. Energy and Buildings, Volume 43, Issue 4, pp. 971-979. 
Musall E., Voss K., 2014, Renewable Energy Ratio in Net

Zero Energy Buildings. REHVA Journal, pp. 14-16.

prEN15603:2013Energy performance of buildingsStandard EPBD.

Reddy B.V.V., 2009, Sustainable materials for low carbon buildings, International Journal of Low-Carbon Technologies, 4(3), 175-181, DOI 10.1093/ijlct/ctp025.

Sadr F., 2014, Heat pumps or CHP - which is greener? REHVA journal, pp. 26-29.

SR EN 1907/1.Method for calculation of the heat design heat load, 1997.

Zirngibil J., 2014, Nearly Zero Energy Buildings (nZEB) in the Cen Draft standard. REHVA Journal, pp 10-13.

Viessmann S.R.L. Design instruction for Heat Pumps. 